\title{
Effects of a spruce budworm outbreak on element export below the rooting zone: a case study for a balsam fir forest
}

\author{
Daniel HoulE ${ }^{1,2}$, Louis DuchEsNE ${ }^{1 *}$, Robert BoutiN ${ }^{3}$ \\ ${ }^{1}$ Direction de la Recherche Forestière, Forêt Québec, Ministère des Ressources Naturelles et de la Faune du Québec, 2700, rue Einstein, Québec, \\ Québec G1P 3W8, Canada \\ ${ }^{2}$ Centre Saint-Laurent, Environnement Canada, 105, rue McGill, Montréal, Québec H2Y 2E7, Canada \\ ${ }^{3}$ Centre de Foresterie des Laurentides, Ressources Naturelles Canada, Service Canadien des forêts, 1055, rue du P.E.P.S., C.P. 3800 Sainte-Foy, \\ Québec G1V 4C7, Canada
}

(Received 24 September 2008; accepted 23 February 2009)

Keywords:

boreal forest /

defoliation /

soil solution /

leaching losses /

nutrient cycles

\begin{abstract}
- Spruce budworm outbreaks are among the major natural disturbances affecting the dynamics and functioning of Canadian boreal forests. However, the element losses potentially associated with spruce budworm outbreaks have not been quantified.

- We evaluated the influence of spruce budworm outbreaks on nutrient export from boreal forest soils by comparing nutrient leaching losses during a spruce budworm outbreaks episode (1981-1984) to an unperturbed period (1999-2003) in a calibrated catchment located in a balsam fir forest.

- Nutrient soil leaching losses were significantly higher during the spruce budworm outbreaks (19811984) for $\mathrm{N}^{-\mathrm{NO}_{3}}$ (30.1 fold), $\mathrm{K}$ (8.3 fold), $\mathrm{N}-\mathrm{NH}_{4}$ (6.2 fold), $\mathrm{Mg}$ (2.7 fold) and $\mathrm{SO}_{4}$ (2.2 fold), as compared to an unperturbed period (1999-2003). When the recurrence of spruce budworm outbreaks (33 years) and a plausible average length of such events ( 5 years) are taken into consideration, it is estimated that in the long term, 5.6 more $\mathrm{NO}_{3}, 1.5$ more $\mathrm{K}$ and 1.2 more $\mathrm{NH}_{4}$ are leached from the soil profile during outbreaks.

- The important leaching losses during spruce budworm outbreaks, when added to the losses due to tree harvesting and fire (and acid deposition for K), may have considerable effects on soil fertility and ecosystem sustainability.
\end{abstract}

\author{
Mots-clés : \\ forêt boréale / \\ défoliation / \\ solution du sol / \\ pertes par lessivage / \\ cycles des nutriments
}

Résumé - Effets d'une attaque de tordeuse des bourgeons de l'épinette sur l'exportation d'éléments au-dessous de la zone racinaire : une étude de cas dans une forêt de sapins baumiers.

- Les épidémies de la tordeuse des bourgeons de l'épinette sont parmi les principales perturbations naturelles qui affectent la dynamique et le fonctionnement des forêts boréales canadiennes. Toutefois, les éléments potentiellement perdus associés à une épidémie de la tordeuse des bourgeons de l'épinette n'ont pas été quantifiés.

- Nous avons évalué l'influence des épidémies de tordeuse des bourgeons de l'épinette sur l'exportation des éléments nutritifs des sols de la forêt boréale, en comparant les pertes par lessivage des éléments nutritifs au cours d'un épisode d'épidémie de la tordeuse des bourgeons de l'épinette (1981-1984) à une période non perturbée (1999-2003) dans un bassin versant calibré situé dans une forêt de sapin baumier.

- Les pertes par lessivage des éléments nutritifs du sol ont été significativement plus élevées au cours

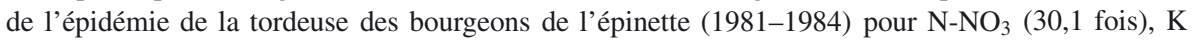

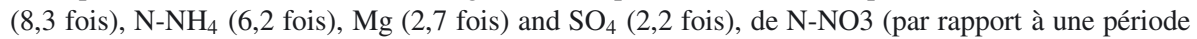
non perturbée (1999-2003). Quand la répétition des épidémies de tordeuse des bourgeons de l'épinette (33 ans) et une durée moyenne plausible de ces événements ( 5 ans) sont prises en considération, il est estimé que dans le long terme, 5,6 fois plus de $\mathrm{NO}_{3}, 1,5$ fois plus de $\mathrm{K}$ et 1,2 fois plus de $\mathrm{NH}_{4}$ sont lessivés du profil du sol durant les épidémies.

- Les importantes pertes par lessivage lors des épidémies de tordeuse des bourgeons de l'épinette, ajoutées aux pertes dues à la récolte des arbres et au feu (et des dépôts acides pour K), peuvent avoir des effets considérables sur la fertilité des sols et la durabilité de l'écosystème.

\footnotetext{
*Corresponding author: louis.duchesne@mrnf.gouv.qc.ca
} 


\section{INTRODUCTION}

Insect outbreaks represent important ecological events that are part of the natural disturbances affecting forest dynamics. Such disturbances may considerably alter the rates of processes that are fundamental to energy, nutrient, and biogeochemical cycling, and drastically reduce uptake by vegetation (MacLean, 1990). In addition to the direct effects on tree growth, increased leaching of nutrients through drainage water has been reported for deciduous forests of the northeastern United States following insect defoliation (Eshleman et al., 1998; Reynolds et al., 2000; Swank et al., 1981; Webb et al., 1995). The higher leaching losses have been attributed to many factors, including increased rates of return from plants to soil through faecal material (Hollinger, 1986), an increase in nutrients returned to soils in insect cadavers that are more easily decomposed than is leaf litter (Schowalter et al., 1986), an increase in nutrient content in throughfall primarily through increased rates of nutrient leaching from damaged leaves, and reduced interception by the canopy (Tukey, 1982). Changes in the quantity and quality of leaf litter (Risley and Crossley, 1993), and increased soil temperature and litter decomposition rates (Reynolds et al. 2000; Webb et al., 1995) also represent plausible explanations. Inorganic $\mathrm{N}$ species, particularly $\mathrm{NO}_{3}$, is the element for which leaching losses are the most often reported. For example, defoliation by the fall cankerworm (Alsophila pometaria) in the southern Appalachians in the USA results in marked changes in the export of nitrate in forest streams (Swank et al., 1981). Likewise, infestations of black locust (Robinia pseudoacacia L.) by the locust stem borer (Megacyllene robiniae) in the same forests coincide with high $\mathrm{NO}_{3}$ export in streams (Crossley et al., 1988). A moderate outbreak of the oak-feeding sawfly (Periclista sp.) in the Appalachians led to a tripling of average frass inputs and to a five-fold increase in soil nitrate availability (Reynolds et al. 2000). Increases in $\mathrm{NO}_{3}$ export have also been observed following gypsy moth (Lymantria dispar) defoliation (Eshleman et al., 1998; Webb et al., 1995). Christenson et al. (2002) have shown that the nitrogen comprised within gypsy moth frass can be rapidly immobilized within the soil in northern hardwood stands. Lovett et al. (2002) suggested that most of the nitrogen released from foliage through defoliation by the gypsy moth is redistributed within other forest compartments, and that leaching losses are relatively small.

In the boreal coniferous forests of Canada and in balsam fir (Abies balsamea (L.) Mill.) dominated stands of the northeastern USA, defoliation caused by spruce budworm (Choristoneura fumiferana [Clem.]) outbreaks is one of the major natural disturbances leading to important tree mortality in balsam fir and spruce (Picea sp.) stands (Morin, 1994). The spruce budworm outbreaks occurred with a recurrence cycle of 33 years, and their effects on forest productivity cannot be compared with any other insect in eastern North America (Morin, 1994; Morin et al. 2007). The effects of spruce budworm outbreaks on forest productivity are even more important than is fire for many regions of eastern North America (Morin et al. 2007). In the province of Québec, for example, the last outbreak (1975-1985) destroyed annually 139 to
238 million $\mathrm{m}^{3}$ of softwood on public lands (Boulet et al., 1996) leading to very important economic losses.

Despite the very dramatic aspects of spruce budworm outbreaks, their effects on nutrient export from boreal forests soils are still not well quantified. A calibrated catchment (Lake Laflamme) in the balsam fir forest was heavily affected by the spruce budworm outbreak between 1976 and 1984. Here, after recovery of tree growth, we compared nutrient leaching losses during this spruce budworm outbreak episode to an unperturbed period (1999-2003).

\section{MATERIAL AND METHODS}

\subsection{Study site}

The Lake Laflamme watershed (LLW), 68 ha in area, is located 70 km north of Québec City, Canada ( $47^{\circ} 19^{\prime} 41^{\prime \prime}$ N; $71^{\circ} 07^{\prime} 37^{\prime \prime}$ W; 771-864 m a.s.1.). The canopy vegetation (1092 stems ha $\left.{ }^{-1}\right)$ is dominated by even-aged balsam fir, with a small component of white spruce (Picea glauca (Moench) Voss) and paper birch (Betula papyrifera Marsh.). Approximately $65 \%$ of the watershed is covered by mature stands $(49.4 \pm 5.5$ years, average \pm standard deviation) in which the average annual increment was approximately equal to the current annual increment. The remaining area is a mixture of windthrow and regeneration. The watershed was affected by a severe spruce budworm outbreak from 1976 to 1984. Between 1981 and 2002 , the average annual mean temperature and precipitation were $0.6{ }^{\circ} \mathrm{C}$ and $1284 \mathrm{~mm}$, respectively, with evapotranspiration losses amounting to $463 \mathrm{~mm}$. The soils are classified as Orthic Humo-Ferric Podzol in the Canadian classification system which corresponds to Spodosols (Haplorthods) in the American classification. The bedrock consists of Precambrian charnorckitic gneiss. More details on study site may be found in previous publications (Houle and Carignan, 1992).

\subsection{Water sampling and analysis}

Between 1981 and 1998, precipitation was sampled daily using an automatic wet-only collector at an open site located at the border of the watershed. After 1998 precipitation was sampled weekly. Stream flow was continuously monitored for water exports, and sampled weekly at a gauge station located at the lake's outlet. Between 1981 and 1988, mineral soil solutions were sampled at six locations in the watershed using tension ceramic cup lysimeters ( $n=2$ to 4 per location) placed at a depth of $30 \mathrm{~cm}$. Forest floor percolates were also sampled with zero tension lysimeters near the open site $(n=3)$ between 1984 and 1988. In 1999, a study plot $(25 \times 50 \mathrm{~m})$ was established in the watershed in order to monitor nutrient fluxes and vegetation. Since then, forest floor percolates have been sampled with four zero tension lysimeters, while the mineral soil solution was sampled with four tension lysimeters located at a depth of $30 \mathrm{~cm}$ and evenly distributed throughout the study plot. Sampling took place weekly from May to October or in the absence of snowpack and frost.

Sample $\mathrm{pH}$ was determined potentiometrically. Basic cations were analysed using atomic absorption or emission between 1981 and 1990 , and subsequently by inductively coupled plasma emission. Nitrate and $\mathrm{SO}_{4}$ were analysed by ion chromatography in all solutions between 1981 and 1998, except for $\mathrm{SO}_{4}$ at the lake's outlet, which 
was analysed by colourimetry. Based on paired samples $(n=42)$, values of $\mathrm{SO}_{4}$ obtained by colourimetric autoanalyser were slightly higher $(11 \%)$ compared to values obtained by ion chromatography. The colourimetric values were thus adjusted by linear regression $\left(R^{2}=0.91\right)$. Analyses for $\mathrm{NH}_{4}$ were done by colourimetry (Technicon AA2).

\subsection{Historical tree growth assessment}

Tree growth was assessed from dendrochronological analysis. In 1998, 50 dominant and codominant balsam fir trees were sampled at the perimeter of the monitoring plot. For each tree sampled, two increment cores were extracted at breast height $(1.3 \mathrm{~m}$ above the highest root) from opposite sides of the bole. Cores were dried, mounted in wooden blocks and sanded for dendrochronological measurements. Ring widths of all cores were cross-dated by visual examination of tree-ring sequence before measurement (squeleton plot procedures) (Fritts, 1976; Yamaguchi, 1991). Ring widths were measured to the nearest $0.01 \mathrm{~mm}$ with a WinDendro Image Analysis System for TreeRing Measurement (Regent Instruments Inc.). Missing and absent rings were added, when necessary, according to standard procedure (Yamaguchi, 1991). Ring width data were verified statistically with the COFECHA program; a quality-control program widely used by dendrochronologists to check the crossdating and overall quality of tree ring chronologies (Holmes, 1996). Cores with rotten heart or cores that could not be cross dated accurately were rejected. A total of 47 trees were used for the subsequent analysis. Previous study has shown that basal area increment (BAI) at breast height is a useful representation of tree vigour and whole-stem growth (Duchesne et al., 2003; LeBlanc, 1990). Annual ring increments were converted to BAI using the formula:

$$
\mathrm{BAI}=\pi\left(R_{n}^{2}-R_{n-1}^{2}\right)
$$

where $R$ is the tree radius and $n$ is the year of tree ring formation. An average ring basal area chronology was generated by averaging the BAI of each tree over each year. The chronology was truncated when less than ten trees were available.

\subsection{Historical spruce budworm defoliation and climate assessment}

The Quebec Department of Natural Resources conducts yearly aerial surveys for spruce budworm within Quebec. Parallel (westeast) flight lines, 5-10 km apart, between latitudes $45^{\circ} \mathrm{N}$ and $50^{\circ} 30^{\prime} \mathrm{N}$ are flown at an elevation of 180-250 m. Surveys are conducted from late June in the southwest of the province to early August in the northeast according to regional climate and tree phenology. A code that describes the average level of tree defoliation ( 0 : no defoliation; 1: low defoliation 1-34\%; 2: moderate defoliation 35-69\%; high defoliation $3: \geq 70 \%$ ) was assigned to each 5 min (longitude) by 5 min (latitude) cell, and cells were identified by the coordinates of their centers. Average cell size was $58 \mathrm{~km}^{2}$ (Gray et al., 2000). In the present study, we used mid-class values for computations.

Long term daily air temperature and precipitation (1948-1999) were computed using BioSIM, a system designed to estimate local weather variables from surrounding meteorological stations. This system performs two main functions: (1) matching geo-referenced sources of weather data to the specified locations, and (2) adjusting data from the selected stations for differences in latitude, longitude, elevation, slope and aspect between the source of weather data and a specified location (Régnière, 1996). The BioSIM model performed very well over a wide range of climatic conditions (Régnière and St-Amant, 2007). In our particular case, a meteorological station located approximately $5 \mathrm{~km}$ from the studied site ensure high correlations between interpolated and observed climatic variables.

\subsection{Fluxes calculation}

Annual (water year: October to September) fluxes in precipitation, soil leaching, and stream water were calculated for $\mathrm{H}, \mathrm{NO}_{3}, \mathrm{NH}_{4}$, $\mathrm{SO}_{4}, \mathrm{~K}, \mathrm{Ca}$ and $\mathrm{Mg}$. Precipitation input were calculated by combining ion concentrations with the cumulative weekly water input. For the soil rooting zone $(50 \mathrm{~cm})$, monthly average soil solution concentrations $(30 \mathrm{~cm})$ were combined with simulated monthly water exports obtained from the FORHYM II hydrological model, which was previously calibrated for the LLW site (Arp and Yin, 1992). The bias of this estimation $(30 \mathrm{~cm}$ concentrations instead of $50 \mathrm{~cm})$ is of small importance for base cation fluxes, which vary slightly with depth (Duchesne and Houle, 2008). Watershed exports were calculated by combining ion concentrations with the cumulative weekly water export. Exports and concentrations during the spruce budworm outbreak (1981-1984) and after (1999-2003) were compared with a Wilcoxon signed-rank test (Wilcoxon, 1945).

\section{RESULTS}

\subsection{Tree growth and spruce budworm outbreak observations}

Most of the watershed was harvested in 1941. Preestablished regeneration reached breast height around 1948 (Fig. 1). Since then, tree growth has ranged from 1.9 to $4.4 \mathrm{~cm}^{2}$ tree $^{-1}$ (mean $=2.6 \mathrm{~cm}^{2}$ tree ${ }^{-1}$ ) except for three distinct periods (1967, 1977-1979 and 1981-1984). During those periods, tree growth averaged $38 \%$ lower $\left(1.6 \mathrm{~cm}^{2}\right.$ tree $\left.{ }^{-1}\right)$ than the mean growth observed over the entire chronology. The relative defoliation, as observed by aerial survey, ranged from 20 to $100 \%$ from 1976 to 1984 , with the exception of 1979 , where no defoliation occurred (Gray et al., 2000). Since 1986, tree growth has been generally higher as compared to the beginning of the chronology.

\subsection{Soil water concentrations and nutrient fluxes}

Forest floor and soil water sample concentrations are presented in Figure 2. Most element concentrations in the forest floor and soil solution were generally higher during the spruce budworm outbreak and declined thereafter. Although the spruce budworm abundance was dramatically reduced in 1985, K and inorganic $\mathrm{N}$ species remained high for a few years afterwards, as compared to the unperturbed period.

Water deposition and water fluxes below the rooting zone and at the stream outlet do not differ significantly during the 


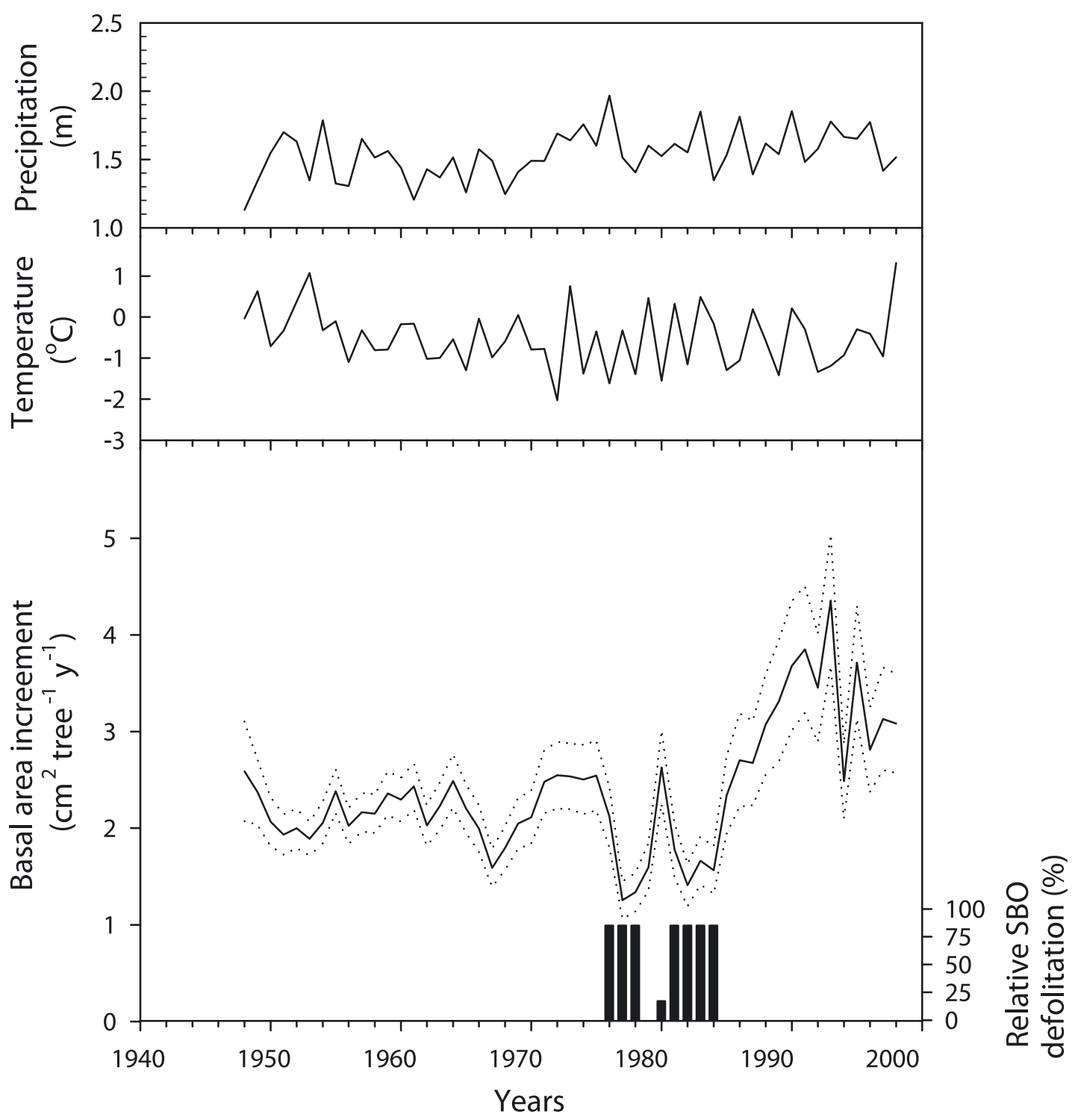

Figure 1. Annual precipitation, mean temperature, basal area increment of dominant and co-dominant balsam fir and relative damage (bottom right axis) caused by the 1976-1984 spruce budworm outbreak. Dotted lines represent \pm 1 standard error.

spruce budworm outbreak and the post-outbreak period ( $p \geq$ 0.24 ). Comparison of precipitation, soil leaching and stream fluxes for the spruce budworm outbreak (1981-1984) period and the post outbreak are presented for each element in Figure 3. Atmospheric wet deposition of $\mathrm{SO}_{4}$ was 1.6 times higher during the spruce budworm outbreak as compared to the post outbreak period ( $p=0.043$ ). Marginally insignificant differences were also observed for atmospheric deposition of $\mathrm{H}$ that was 1.5 -fold higher ( $p=0.083$ ). Soil leaching of $\mathrm{H}, \mathrm{K}, \mathrm{Ca}$, $\mathrm{Mg}, \mathrm{N}-\mathrm{NH}_{4}, \mathrm{~N}_{-} \mathrm{NO}_{3}$ and $\mathrm{SO}_{4}$ were $2.3,8.3,2.4,2.7,6.2,30.1$ and 2.2 times higher, respectively, during the spruce budworm outbreak as compared to post outbreak values $(p \leq 0.043)$. Stream flow exports of $\mathrm{Mg}$ were relatively similar, while $\mathrm{H}$, $\mathrm{Ca}$ and $\mathrm{N}-\mathrm{NO}_{3}$ stream exports were lost in greater amounts during the spruce budworm outbreak $(p \leq 0.043)$.

\section{DISCUSSION}

\subsection{The effect of the spruce budworm outbreak on tree growth}

The growth reduction during the 1977-1979 and 19811984 periods are not related to any particular climatic episodes but are synchronized with the defoliation caused by the spruce budworm as observed by aerial surveys (Fig. 1). Mean annual basal area increment during the spruce budworm outbreak is $38 \%$ lower than the average growth since 1948. Such an effect of spruce budworm outbreak on growth is typical for coniferous sites (Morin et al., 2007). The short burst of higher growth rate in 1980 was likely due to a strong decrease in spruce budworm abundance. This pattern of strongly reduced budworm 

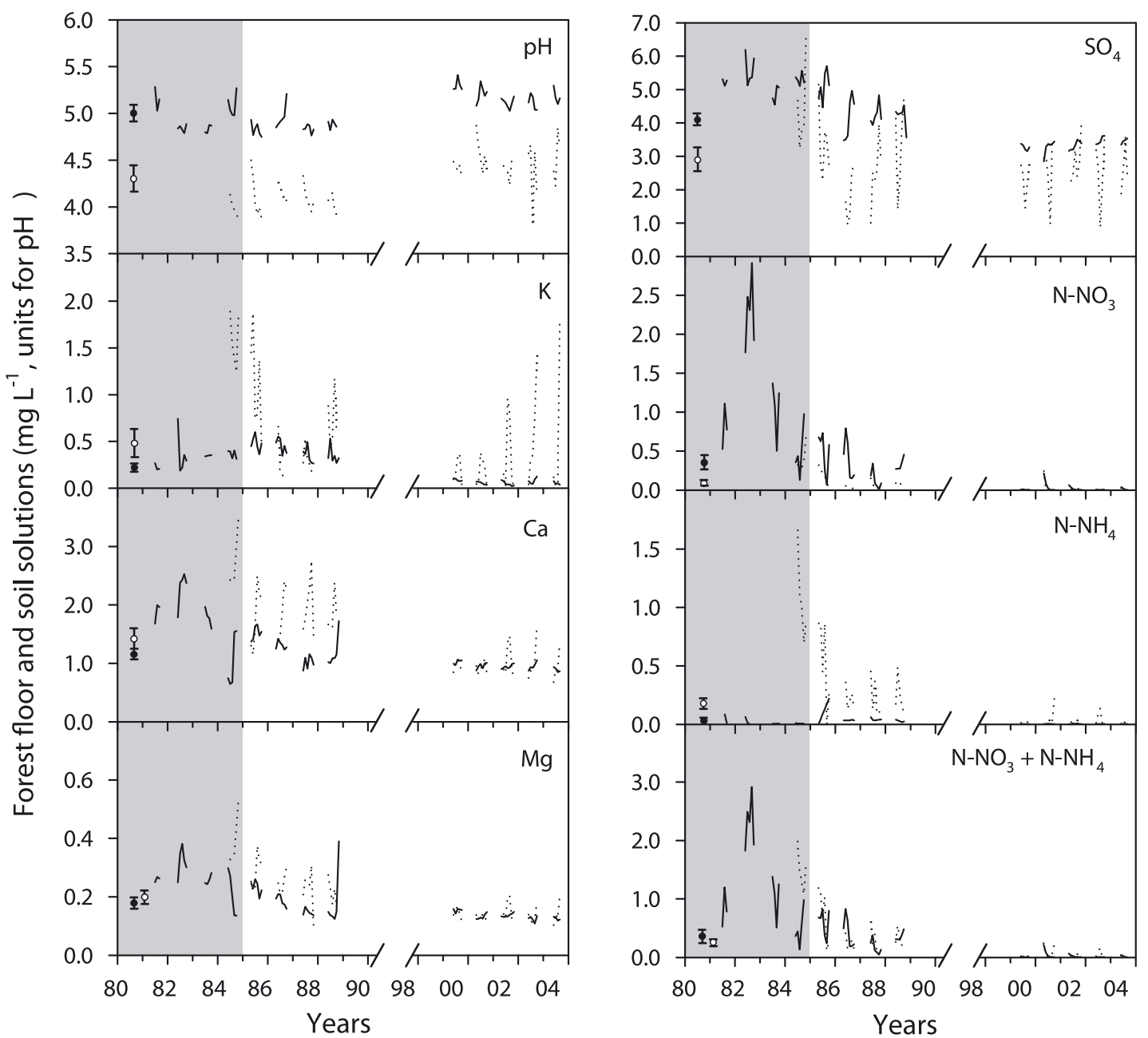

Figure 2. Temporal variations of major ions in the forest floor (dotted line) and the mineral soil (straight line) percolates. The shaded areas represent the spruce budworm outbreak period. Error bars on the left indicate average standard error of monthly concentrations.

abundance within the middle of an outbreak has been observed for large portions of the landscape in the provinces of Québec (Gray et al., 2000; Jardon and Morin, 2003) and Nova Scotia (Ostaff and MacLean, 1995).

Tree growth is generally higher following spruce budworm outbreak as compared to the beginning of the chronology. We suggest that remnant trees that were not killed during the spruce budworm outbreak benefited from space created by the mortality of some individuals, and consequently exhibit higher growth. Tree growth was also considerably reduced in 1967. However, that year does not correspond to any report of spruce budworm outbreak in the province (Gray et al., 2000; Jardon and Morin, 2003). Climate records from the Québec City airport indicated that 1967 was the coldest spring (March-May; $0.1{ }^{\circ} \mathrm{C}$, normal $=3.3{ }^{\circ} \mathrm{C}$ ) and the wettest summer (JuneAugust; $496 \mathrm{~mm}$, normal $=359 \mathrm{~mm}$ ) recorded since 1943 (CRIACC, 2008). Such extreme climate conditions may have had considerable effects on tree growth (Fritts, 1976). Consequently, we suggest that the 1967 growth reduction was related to climate.

\subsection{The effect of spruce budworm outbreak on soil leaching exports}

Very important differences in soil leaching exports (and to a lesser extent in streams) were observed when the spruce budworm outbreak and the unperturbed period were compared. The differences were particularly important for inorganic $\mathrm{N}\left(\mathrm{NO}_{3}+\mathrm{NH}_{4}\right)$ and $\mathrm{K}$, two elements known to be actively recycled through biotic reactions in forest soils (Aber and Driscoll, 1997; Likens et al., 1994; Johnson et al., 2008). The higher inorganic $\mathrm{N}$ and $\mathrm{K}$ exports during the spruce budworm outbreak cannot be attributed to higher atmospheric fluxes of these elements, because there were no significant differences in wet deposition of these elements between the time of the spruce budworm outbreak and the unperturbed period. Other factors known to affect $\mathrm{N}$ cycling, such as climate fluctuations (Mitchell et al., 1996) cannot be supported because temperature and precipitation during the growing season (June-September) were not different between the two periods $\left(12.7 \pm 1.5\right.$ vs. $13.6 \pm 0.9^{\circ} \mathrm{C}$ and $352 \pm 122 \mathrm{~mm}$ vs. $362 \pm 103 \mathrm{~mm}$ 


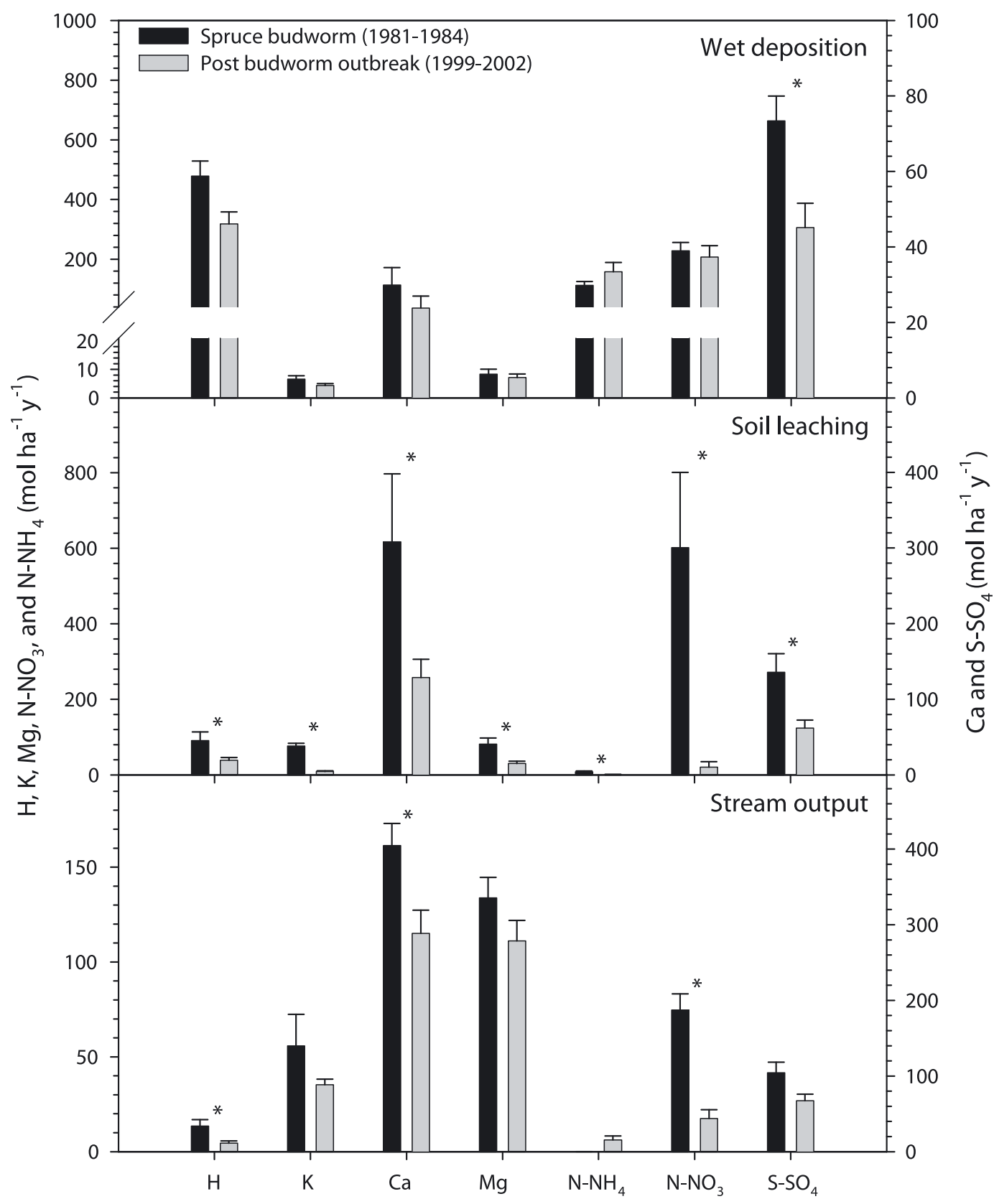

Figure 3. Atmospheric depositions and soil and stream major ion fluxes during the spruce budworm outbreak period and the post outbreak period. Error bars show the Standard Error. Test significance: * $p \leq 0.05$, ** $p \leq 0.01, * * * p \leq 0.001$.

for the spruce budworm outbreak and unperturbed period respectively; $p \geq 0.15$ ). In fact, annual $\mathrm{NO}_{3}$ concentration and export, both in the soil solution below the rooting zone and at the stream watershed output, were not correlated to annual $\mathrm{N}$ depositions or to annual precipitation and temperature. However, stong correlations were found between the percent of defoliation attributable to the spruce budworm outbreak and $\mathrm{NO}_{3}$ concentrations in the soil solution $(r=0.84)$ and the stream $(r=0.96)$. We thus considered that the high soil leaching losses of elements during the spruce budworm outbreak was a direct consequence of the spruce budworm outbreak it- self. Although such a potential impact of spruce budworm outbreak could have been expected, the leaching losses caused by such a perturbation have never been quantified before.

\subsection{Inorganic $N$ species}

Some studies have shown similar strong effects on $\mathrm{NO}_{3}$ leaching for different degrees of defoliation caused by different species of insect outbreaks in the northeastern USA (Eshleman et al., 1998; Lewis, 1998; Reynolds et al., 2000; 
Swank et al., 1981; Webb et al., 1995). The reduction (up to $38 \%$ ) in annual balsam fir growth (Fig. 1), and therefore in nutrient uptake, could explain a part of the higher $\mathrm{N}$ (and K) leaching losses during the spruce budworm outbreak. For example, if we assume that the reduction in total $\mathrm{N}$ uptake (900 $\mathrm{mol} \mathrm{ha}^{-1} \mathrm{y}^{-1}$, unpublished data) was nearly proportional to the reduction in growth, then, a difference of $343 \mathrm{~mol} \mathrm{ha}^{-1} \mathrm{y}^{-1}$ in tree uptake could be potentially available for leaching, which would represent $55 \%$ of total soil $\mathrm{N}$ leaching losses. Defoliation may have had indirect effects, such as decreasing the above-ground biomass water uptake and increasing light transmission to the forest floor, thus increasing soil moisture and soil temperature. This situation is likely favourable to increased microorganism activity, and hence increased soil organic matter (and organic $\mathrm{N}$ ) decomposition rates.

Decomposition of budworm excreta and cadavers may also contribute to $\mathrm{N}$ leaching, since insects can convert an important part of the $\mathrm{N}$ sequestered in the needle canopy, which amounts to $12500 \mathrm{~mol} \mathrm{ha}^{-1}$ at our site (unpublished data) to readily available organic $\mathrm{N}$ and $\mathrm{NH}_{4}$ (Hollinger, 1986). The soil rooting zone inorganic $\mathrm{N}$ exports during the spruce budworm outbreak were $610 \mathrm{~mol} \mathrm{ha}^{-1} \mathrm{y}^{-1}$, as compared to $341 \mathrm{~mol} \mathrm{ha}^{-1} \mathrm{y}^{-1}$ for atmospheric wet deposition, clearly showing that internal sources contributed to the soil leaching export. This situation is in contrast with the unperturbed period during which inorganic $\mathrm{N}$ is strongly retained within the soil. In fact, the inorganic $\mathrm{N}$ exports below the rooting zone were 30 times higher during the spruce budworm outbreak than during the undisturbed 1999-2002 period, with $\mathrm{NO}_{3}$ comprising $67 \%$ of the total inorganic $\mathrm{N}$ exports.

Most of the high $\mathrm{NO}_{3}$ exports following insect outbreaks were reported for deciduous forests (Lewis, 1998; Webb et al., 1995). The high $\mathrm{N}-\mathrm{NO}_{3}$ exports below the rooting zone for the LLW is surprising, given the inhibiting effect of the high phenolic content of balsam fir litter (Baldwin et al., 1983; Olson and Reiners, 1983; Thibault et al., 1982). In addition, nitrification rarely occurs under pH 4.5 (Rudebeck and Persson, 2000; Ste-Marie and Paré, 1999), while the humus layer pH during the spruce budworm outbreak was 4.3. To examine more closely the inorganic $\mathrm{N}$ fluxes within the soil profile, we used data from 1985 for which LFH fluxes were available. Although the spruce budworm outbreak was nearly over by 1985 , the effect clearly persisted for a few years afterwards, as shown by the high $\mathrm{K}$ and inorganic $\mathrm{N}$ concentrations in the soil lysimeters (Fig. 2) that remained high as compared to the unperturbed period. This is probably due to tree mortality, which may reach 20 to $25 \%$ following intense spruce budworm outbreak, while foliage reconstitution and growth of living trees may need 5 to 7 years before totally recovering (Ostaff and MacLean, 1995). As a result, openings in the canopy may persist for a few years after the end of the outbreak, enhancing light and rain penetration to the forest floor and potentially favouring higher organic matter decomposition rates. Moreover, the dead tree organic matter, particularly within the needles and the small branches, may constitute readily available sources of $\mathrm{K}$ and $\mathrm{N}$ that may continue to be lost for a few years following the outbreak. Although, mortality data were not available for the
Lake Laflamme site, Houle and Carignan (1992) reported that freshly fallen dead balsam fir on the ground represented up to $25 \%$ of the total tree biomass at the LLW site in 1988, suggesting that balsam fir mortality was important.

The examination of the 1985 data suggests that $\mathrm{N}$ transformation processes were profoundly disturbed within the soil profile as a result of the spruce budworm outbreak. Important amounts of N-NH$\left(376 \mathrm{~mol} \mathrm{ha}^{-1} \mathrm{y}^{-1}\right)$ were exported below the forest floor, contributing to nearly $90 \%$ of the total inorganic $\mathrm{N}$ fluxes $\left(418 \mathrm{molha}^{-1} \mathrm{y}^{-1}\right)$ as compared to insignificant $\mathrm{N}-\mathrm{NH}_{4}$ fluxes during the unperturbed period. Although the amount of inorganic $\mathrm{N}$ exported from the mineral soil was nearly similar $\left(201 \mathrm{~mol} \mathrm{ha}^{-1} \mathrm{y}^{-1}\right)$ to the amount exported below the humus layer, $67 \%$ of it was composed of $\mathrm{N}^{-\mathrm{NO}_{3}}$, demonstrating that incoming $\mathrm{NH}_{4}$ from the humus layer was almost totally nitrified within the mineral soil. The higher pH (average 4.9, Fig. 2) and lower dissolved organic carbon (DOC) (average $4.6 \mathrm{mg} \mathrm{L}^{-1}$, unpublished data) concentrations (and presumably phenolic compounds) found in the mineral soil solution, as compared to the low pH (average 4.3) and the high DOC (average $22.4 \mathrm{mg} \mathrm{L}^{-1}$, unpublished data) of the forest floor solution was probably a factor explaining the intense nitrification within the mineral soil.

Although the $\mathrm{N}-\mathrm{NO}_{3}$ export at the catchment scale was 4.2 times higher during the spruce budworm outbreak $\left(75 \mathrm{molha}^{-1} \mathrm{y}^{-1}\right)$ than during the unperturbed period $\left(18 \mathrm{~mol} \mathrm{ha}^{-1} \mathrm{y}^{-1}\right)$, it was clearly lower than the spruce budworm outbreak soil leaching losses $\left(602 \mathrm{~mol} \mathrm{ha}^{-1} \mathrm{y}^{-1}\right)$ (Fig. 3). One possibility to explain this difference is that the $\mathrm{NO}_{3}$ exported from mid-slope sites may have been taken up by trees and/or soil microorganisms lower on the watershed slope before reaching the lake. There is a small abundance of cedar trees surrounding the lake perimeter that may have sequestered a part of the incoming $\mathrm{NO}_{3}$. It seems doubtful, however, that they could uptake such an important proportion of the $\mathrm{NO}_{3}$ lost upslope. Important in-lake losses may also have occured via (1) denitrification in the riparian zone and within the oxygenfree, organic-rich sediment belting the lake, (2) uptake by the important macrophyte community at the lake littoral, and finally (3) phytoplankton uptake followed by sedimentation.

\subsection{Cation losses}

The loss of K through soil leaching (Fig. 3) was particularly high $\left(76.4 \mathrm{~mol} \mathrm{ha}^{-1} \mathrm{y}^{-1}\right)$ during the spruce budworm outbreak as compared to $1999-2002$ values $\left(9.4 \mathrm{~mol} \mathrm{ha}^{-1} \mathrm{y}^{-1}\right)$. For example, soil exports of $\mathrm{K}$ during the spruce budworm outbreak were 8.3 times higher than 1999-2002 values, as compared to 2.4- and 2.7-fold for $\mathrm{Ca}$ and $\mathrm{Mg}$, respectively. The $\mathrm{K}$ concentration in soil solution remained high until 1988, while other cations showed earlier signs of recovery (Fig. 2). Potassium is a highly mobile element whose tight retention in the rooting zone of forest ecosystems is ensured almost exclusively by biotic processes. The large $\mathrm{K}$ losses during the spruce budworm outbreak were thus indicative of a breakdown of biological retention mechanisms as also evidenced by the high $\mathrm{NO}_{3}$ exports discussed above. Several studies of insect outbreaks 
have also demonstrated increased basic cation export following intense defoliation (Eshleman et al., 1998; Reynolds et al., 2000; Swank et al., 1981; Webb et al., 1995). Many of the reasons used above to explain the higher $\mathrm{N}$ fluxes also hold for $\mathrm{K}$ losses, including lower tree uptake and increased organic matter decomposition rates.

Catchment losses of $\mathrm{K}$ during the spruce budworm outbreak were lower than the soil leaching losses, but the differences were not as important as for $\mathrm{NO}_{3}$. The biotic uptake that may potentially occur (trees and macrophytes) at the lake littoral vicinity as described above may also explain the difference in $\mathrm{K}$ fluxes. In addition, a susbtantial portion of the catchment $\mathrm{K}$ exports originates from weathering of the till located below the rooting zone (Duchesne and Houle, 2008). Consequently, the signal of an important biotic source of $\mathrm{K}$ during the spruce budworm outbreak is somehow diluted in the $\mathrm{K}$ provided by weathering, which is not the case for $\mathrm{NO}_{3}$ for which the weathering contribution is negligeable.

The relatively low losses of $\mathrm{Ca}$ and $\mathrm{Mg}$ as compared to $\mathrm{K}$ during the spruce budworm outbreak may be explained by the fact that $\mathrm{Ca}$ and $\mathrm{Mg}$ both have a high capacity to adsorb within the soil exchangeable complex, contrary to K. They are thus less sensitive to losses than elements that cycle almost entirely through biotic reactions, such as $\mathrm{K}$ and inorganic $\mathrm{N}$ species. Soil solution leached from reconstructed soil columns from LLW revealed a similar pattern of cation leaching with endogenous nitrate production (Boutin and Robitaille, 1989). In addition, $\mathrm{Ca}$ and $\mathrm{Mg}$ losses are often associated with soil leaching losses of $\mathrm{SO}_{4}$ (Reus and Johnson, 1985). Regulations to control air pollution in the United States and Canada were significantly strengthened and expanded in 1990, with the ratification of the Clean Air Act Amendment (CAAA) in the USA. Consequently, in Canada and the USA, total $\mathrm{SO}_{2}$ emissions have declined by approximately $50 \%$ and $40 \%$, respectively, between 1980 and 2000 and are predicted to continue to decline between 2000 and 2020 (Niemi, 2004). The fact that both $\mathrm{SO}_{4}$ wet deposition and leaching were significantly higher during the spruce budworm outbreak may explain in part the higher $\mathrm{Ca}$ and $\mathrm{Mg}$ losses during this period.

\section{CONCLUSION}

For the first time, the nutriment losses associated with spruce budworm outbreak have been quantified. During the spruce budworm outbreak, the soil leaching losses of $\mathrm{N}-\mathrm{NO}_{3}$, $\mathrm{N}-\mathrm{NH}_{4}$ and $\mathrm{K}$ were increased by 30.1-, 6.2- and 8.3-fold, respectively, as compared to the unperturbed period. The disruption of tree uptake as well as an increased rate of organic matter decomposition are likely responsible for the high exports observed during the spruce budworm outbreak. When the recurrence of spruce budworm outbreak (33 y) and a plausible average length of such events $(5 \mathrm{y})$ are taken into consideration, it is estimated that in the long term, 5.6 times more $\mathrm{NO}_{3}$, 1.5 times more $\mathrm{K}$ and 1.2 times more $\mathrm{NH}_{4}$ are leached from the soil profile during outbreaks. The important leaching losses during spruce budworm outbreak, when added to the losses caused by tree harvesting and fire (and acid deposition for K) may have considerable effects on soil fertility and ecosystem sustainability.

Acknowledgements: This research was supported by the Ministère des Ressources naturelles, de la Faune et des Parcs du Québec, project number 0317 3067, and by the Long Range Transport of Air Pollutants program (LRTAP) of the Canadian Forest Service, which initiated the nutrient cycling research at LLW in 1981. We would like to thank J. Gagné, M. St-Germain, B. Toussaint and J. Martineau for field assistance, the chemistry laboratory of the Direction de la recherche forestière (MRNF) for the chemical analyses and also all the field and laboratory staff who worked on the acid rain project at the Laurentian Forestry Centre (Natural Resources Canada- Canadian Forest Service) in Québec City.

\section{REFERENCES}

Aber J.D. and Driscoll C.T., 1997. Effects of land use, climate variation and $\mathrm{N}$ deposition on $\mathrm{N}$ cycling and $\mathrm{C}$ storage in northern hardwood forests. Global Biochem. Cy. 11: 639-648.

Arp P.A. and Yin X., 1992. Predicting water fluxes through forests from monthly precipitation and mean monthly air temperature records. Can. J. For. Res. 22: 864-877.

Baldwin I.T., Olson R.K., and Reiners W.A., 1983. Protein binding phenolics and the inhibition of nitrification in subalpine balsam fir soils. Soil Biol. Biochem. 15: 419-423.

Boulet B., Chabot M., Dorais L., Dupont A., and Gagnon, R., 1996. Entomologie forestière. In: Ordre des ingénieurs forestiers (Ed.), Manuel de foresterie, les Presses de l'Université Laval, Québec, pp. $1008-1043$.

Boutin R. and Robitaille G., 1989. Effects of in vitro acidification of a Podzol on the chemistry of percolates and horizons. Inf. Rep. LAUX-91A, Forestry Canada, Quebec Region.

Christenson L.M., Lovett G.M., Mitchell M.J., and Groffman P.M., 2002. The fate of nitrogen in gypsy moth frass deposited to an oak forest floor. Oecologia 131: 444-452.

Couture S., 1995. Response of the Laflamme Lake watershed, Quebec, to reduced sulphate deposition (1981-1992). Can. J. Fish. Aquat. Sci. 52: 1936-1943.

CRIACC, 2008. Centre de ressources en impacts et adaptation aux changements climatiques. [online]. Available from http://www. criacc.qc.ca/ [accessed August 6 2008].

Crossley D.A. Jr., Gist C.S., Hargrove W.W., Risley L.S., Schowalter T.D., and Seastedt T.R., 1988. Foliage consumption and nutrient dynamics in canopy insects. In: Swank W.T. and Crossley D.A. Jr. (Eds.), Forest hydrology and ecology at Coweeta, Springer-Verlag, New York, pp. 193-205.

Duchesne L., Ouimet R., and Morneau C., 2003. Assessment of sugar maple health based on basal area growth pattern. Can. J. For. Res. 33: 2074-2080.

Duchesne L. and Houle D., 2008. Impact of nutrient removal through harvesting on the sustainability of the boreal forest. Ecol. Appl. 18: $1642-1651$.

Eshleman K.N., Morgan R.P. II, Webb J.R., Deviney F.A., and Galloway J.N., 1998. Temporal patterns of nitrogen leakage from midAppalachian forested watersheds: role of insect defoliation. Water Resour. Res. 34: 2005-2116.

Fritts H.C., 1976. Tree rings and climate, academic press, London, 567p.

Gouvernement du Québec, 2002. ressources et industrie forestières. Portrait statistique, Édition 2002. Ministère des Ressources Naturelles, 64 p. 
Gray D.R., Régnière J., and Boulet B., 2000. Analysis and use of historical patterns of spruce budworm defoliation to forecast outbreak patterns in Quebec. For. Ecol. Manage. 127: 217-231.

Hollinger D.Y., 1986. Herbivory and the cycling of nitrogen and phosphorus in isolated California oak trees. Oecologia 57: 14-19.

Holmes R.L., 1996. Dendrochronology program library, version 2.0. Laboratory of Tree-Ring Research, University of Arizona, Tucson, AZ.

Houle D. and Carignan R., 1992. Sulfur distribution and speciation in soils and aboveground biomass of a boreal coniferous forest. Biogeochem. 16: 63-82.

Jardon Y. and Morin H., 2003. Périodicité des épidémies de la tordeuse des bourgeons de l'épinette au cours des deux derniers siècles. Can. J. For. Res. 33: 1947-1961.

Johnson, D.W., Murphy, J.D., Walker, R.F., Miller, W.W., and Glass, D.W., 2008. The combined effects of thinning and prescribed fire on carbon and nutrient budgets in a Jeffrey pine forest. Ann. For. Sci. 65: 601 .

LeBlanc D.C., 1990. Relationships between breast-height and wholestem growth indices for red spruce on Whiteface Mountain. New York. Can. J. For. Res. 20: 1399-1407.

Lewis G.P., 1998. Response of stream chemistry to forest insect defoliation on the Allegheny High Plateau, Pennsylvania. Ph.D. dissertation, Cornell University, Ithaca, New York.

Likens G.E., Driscoll C.T., Buso D.C., Siccama T.G., Johnson C.E., Ryan D.F., Lovett G.M., Fahey T.J., and Reiners W.A., 1994. The biogeochemistry of potassium at Hubbard Brook. Biogeochemistry 25: 61-125.

Lovett G.M., Christenson L.M., Groffman P.M., Jones C.G., Hart J., and Mitchell, M.J., 2002. Insect defoliation and nitrogen cycling in forests. BioScience 52: 335-341.

MacLean D.A., 1990. Impact of forest pests and fire on stand growth and timber yield: implications for forest management planning. Can. J. For. Res. 20: 391-404.

Mitchell M.J., Driscoll C.T., Kahl J.S., Likens G.E., Murdoch P.S., and Pardo L.H., 1996. Climatic control of nitrate loss from forested watersheds in the northeast United States. Environ. Sci. Technol. 30: 2609-2612.

Morin H., 1994. Dynamics of balsam fir forests in relation to spruce budworm outbreaks in the boreal zone of Quebec. Can. J. For. Res. 24: $730-741$.

Morin H., Jardon Y., and Gagnon R., 2007. Effects of insect outbreaks on forest dynamics. In: Johnson E.A. and Miyanishi K. (Eds.), Plant disturbance ecology: the process and the response, Academic Press, pp. 555-564

Niemi, D. 2004. Emissions of pollutants related to acid deposition in North America. In: Canadian acid deposition science assessment, Meteorological Service of Canada, Environment Canada, pp. 5-14.
Olson R.K. and Reiners W.A., 1983. Nitrification in subalpine balsam fir soils: tests for inhibitory factors. Soil Biol. Biochem. 15: 413-418.

Ostaff D.P. and MacLean D.A., 1995. Patterns of balsam fir foliar production and growth in relation to defoliation by spruce budworm. Can. J. For. Res. 25: 1128-1136.

Piene, H., 1989. Spruce budworm defoliation and growth loss in young balsam fir: defoliation in spaced and unspaced stands and individual tree survival. Can. J. For. Res. 19: 1211-1217.

Régnière J., 1996. Generalized approach to landscape-wide seasonal forecasting with temperature-driven simulation models. Environ. Entomol. 25: 869-881.

Régnière, J. and R. St-Amant. 2007. Stochastic simulation of daily air temperature and precipitation from monthly normals in North America north of Mexico. Int. J. Biometeorol. 51: 415-430.

Reuss J.O. and Johnson D.W., 1985. Effects of soil processes on the acidification of water by acid deposition. J. Env. Qual. 12: 26-31.

Reynolds B.C., Hunter M.D., and Crossley D.A. Jr, 2000. Effects of canopy herbivory on nutrient cycling in a northern hardwood forest in western North Carolina, Selbyana 21: 74-78.

Risley L.S. and Crossley D.A. Jr., 1993. Contribution of herbivore caused greenfall to litterfall $\mathrm{N}$ flux in several southern Appalachian forested watersheds. Am. Midl. Nat. 129: 67-74.

Rudebeck A. and Persson T., 2000. Net nitrogen mineralization and net nitrification in European forest soils in response to manipulation of pH. Acta Universitatis Agriculturae Sueciae, Silvestria 145: 20-42.

Schowalter T.D., Hargrove W.W., and Crossley D.A. Jr, 1986. Herbivory in forested ecosystems. Annu. Rev. Entomol. 31: 177-196.

Ste-Marie C. and Paré D., 1999. Soil, pH and N availability effects on net nitrification in the forest floors of a range of boreal forest stands. Soil Biol. Biochem. 31: 1579-1589.

Swank W.T., Waide J.B., Crossley D.A., and Todd R.L., 1981. Insect defoliation enhances nitrate export from forest ecosystems. Oecologia 51: $297-299$.

Thibault J.R., Fortin J.A., and Smirnoff W.A., 1982. In vitro allelopathic inhibition of nitrification by balsam poplar and balsam fir. Am. J. Bot. 69: 676-679.

Tukey H.B. and Morgan J.V., 1963. Injury to foliage and its effects upon the leaching of nutrients from above-ground plant parts. Physiol. Planta 16: 557-564.

Webb J.R., Cosby B.J., Deviney F.A., Eshleman K.N., and Galloway J.N., 1995. Change in the acid-base status of an Appalachian catchment following forest defoliation by the gypsy moth. Water Air Soil Pollut. 85: 535-540.

Wilcoxon, F. 1945. Individual comparisons by ranking methods. Biometrics 1: 80-83.

Yamaguchi D.K., 1991. A simple method for cross-dating increment cores from living trees. Can. J. For. Res. 21: 414-416. 